\author{
PAWEE MUNiAK \\ Wydział Biologii \\ Uniwersytet Jagielloński \\ Gronostajowa 7, 30-387 Kraków \\ E-mail: pawel.muniak@student.uj.edu.pl
}

\title{
PROCES WYMIANY ZĘBÓW U WYBRANYCH GRUP SSAKÓW W UJĘCIU EWOLUCYJNYM
}

\section{WSTEP}

Wymiana zębów u zwierząt kręgowych jest ważnym zjawiskiem zarówno w skali osobnika, zwiększajacym jego dostosowanie do środowiska i co za tym idzie, szanse przeżycia, jak i w szerszej perspektywie ewolucyjnej, pokazujac trendy ewolucyjne w obrębie całych grup.

Wymiana uzębienia jest powszechna wśród zwierząt. Większość zwierząt posiadajacych zęby wymienia je na nowe, stosujacc różne strategie. Najczęstszym typem wymiany jest polifiodoncja. Polega ona na tym, że utracony zab jest zastępowany przez nowy, wyrastający na jego miejscu. W taki sposób wymienia zęby większość gadów, u których wymieniane sa one w sposób przypadkowy: gdy jeden ulegnie złamaniu lub wypadnie, na jego miejsce wyrasta nowy. U ryb chrzęstnoszkieletowych, w tym rekinów, znane sa inne mechanizmy wymiany uzębienia, tzn. spirale zębowe, pozwalające na wymianę całej serii zębów w miarę ich zużywania, począwszy od najstarszych i najbardziej zużytych, znajdujących się na krańcu spirali.

U gadów wyróżniamy kilka typów osadzenia zębów w szczękach. Najpierwotniejszy jest typ akrodontyczny, polegajacy na tym, że ząb umieszony jest na wierzchołku krawędzi kostnej. Ten typ występuje również u ryb i płazów. Większość gadów cechuje jednak typ pleurodontyczny, charakteryzujacy się przyrośnięciem do wewnętrznego obszaru kości (SZARSKI 1978). Ostatni typ wystepujący tylko u krokodyli oraz u ssaków to typ tekodontyczny. Każdy ząb w tym przypadku umieszczony jest w zębodole. Ssaki sa pod względem wymiany zębowej wyjątkowe, gdyż tylko u nich widać kształtująca się w ciagu ewolucji tendencje do difiodoncji, czyli wytwarzania jedynie dwóch pokoleń zębów: mlecznych i stałych, wymienianych w skoordynowany sposób w ciagu krótkiego czasu życia zwierzęcia (zazwyczaj pomiędzy ukończeniem stadium oseska a dojrzałościa płciowa) (SZARSKI 1998).

\section{TERMINOLOGIA}

W niniejszej pracy będę posługiwał się ogólnie przyjętymi skrótami $z$ terminologii anatomicznej, gdzie zęby szczęki (górne) będa oznaczane wielka literą: I, C, P, M, a zęby żuchwy (dolne) mała literą: i, c, p, m. I tak:

$\mathrm{I} / \mathrm{i}$ - siekacz,

$\mathrm{C} / \mathrm{c}$ - kieł

$\mathrm{P} / \mathrm{p}$ - zab przedtrzonowy,

$\mathrm{M} / \mathrm{m}$ - ząb trzonowy.

Cyfra przy każdym zębie wskazuje na położenie w rzędzie zębowym, np. M1 to pierwszy ząb trzonowy górny.

Zęby mleczne będa zapisywane skrótem zaczynającym się od litery „d" (od łac. deciduus, ang. deciduous, przemijający), np. dI1 - mleczny pierwszy siekacz górny.

Zęby, które zostają zastępowane przez nowe wiele razy, czyli maja więcej niż dwie generacje, będa zapisywane skrótem zaczynającym się od litery „r”, np. rM1. Wzór zębowy podawany dla każdej $z$ omawianych grup będzie zatem wyglądał następujaco: Ix/ ix-Cx/cx-Px/px-Mx/mx, gdzie „x” oznacza liczbę zębów danego typu. 


\section{WYMIANA ZĘBÓW U SSAKÓW}

Formowanie całych generacji zębowych jest u ssaków zjawiskiem wieloczynnikowym, niewątpliwie częściowo związanym $z$ powstaniem zróżnicowanego uzębienia (heterodoncja) w tej grupie i $z$ determinacja wzrostu czaszki u dorosłych osobników. Czaszka gadów rośnie przez całe życie zwierzęcia, stąd pojawia się konieczność zastępowania mniejszych zębów młodocianych proporcjonalnie większymi, bardziej dopasowanymi do rozmiarów czaszki osobnika dorosłego. U większości gadów, oprócz niektórych dinozaurów i zaawansowanych gadów ssakokształtnych (KEMP 2005, WEISHAMPEL i współaut. 2007), brak jest zróżnicowanego uzębienia; maja one uzębienie homodontyczne, czyli takie, w którym każdy ząb (przeważnie stożkowatego kształtu) jest zbliżony do innych kształtem i rozmiarami (LUO i współaut. 2004, BENTON 2015). Ssaki natomiast maja uzębienie heterodontyczne, charakteryzujące się zróżnicowaniem zębów w rzędzie zębowym pod względem wielkości, kształtu i funkcji (KEMP 2005). W pełnym uzębieniu ssaków wyróżniamy zatem: siekacze, kły, przedtrzonowce i trzonowce. Siekacze, kły i przedtrzonowce maja dwie generacje uzębienia, natomiast trzonowce jako jedyne nie sa wymieniane i sa częścią stałego uzębienia. Co istotne, każdy ząb policzkowy wymieniany na nowy zab jest uważany za przedtrzonowiec, nawet jeżeli jego struktura jest trzonowcowa (LUO i współaut. 2004). Istotna jest definicja trzonowców ze względu na to, że uwzględnia ona tylko gatunki współczesne, natomiast znane sa gatunki wymarłe wymieniajace tylne zęby zakłowe, które nie sa nazywane przedtrzonowcami, tylko zębami trzonowcokształtnymi.

Już na przełomie triasu i jury (czyli około $200 \mathrm{mln}$ lat temu) zaszły przekształcenia, które doprowadziły do powstania swoistej cechy, jaka jest difiodoncja u ssaków. Przejście od polifiodoncji do difiodoncji było spowodowane w szczególności tym, że ssaki w czasie swojej wczesnej ewolucji utraciły cechę, jaka jest niezdeterminowany wzrost czaszki (i całego ciała). Badania paleontologiczne dotyczace morganukodona i sinokonodona wykazały, że im większy wzrost czaszki u osobnika, tym większa, liczniejsza generacja zębów. Sinoconodon charakteryzował się większym zakresem rozmiarów czaszki, co korelowało $z$ wielokrotna wymiana uzębienia. $Z$ kolei Morganucodon miał dwie generacje uzębienia i, jak wykazują badania, zarazem znacznie mniejszy zakres rozmiaru czaszki (LUO i współaut. 2004). Kolejną cechą, która przybliżała ssaki do difiodoncji, było powstanie zróżnicowania zębów. U pierwotnych ssaków (w szczególności u sinokonodona) istotne było zróżnicowanie się przedtrzonowców i trzonowców. Tylne trzonowce nadal były w tych grupach wymieniane na nowe zęby. Zmiany, które dokonały się na przełomie triasu i jury doprowadziły do całkowitej difiodoncji u morganukodona. Natomiast niektóre gatunki $\mathrm{z}$ wczesnej kredy posiadały cechy prymitywne, takie jak unikatowa jak na ssaki, wymianę części trzonowców na nowe. Kolejne wymarłe grupy ssaków, począwszy od rodzaju Sinoconodon, wykazuja stopniowe zmiany procesu wymiany zębów, które doprowadziły do difiodoncji, czyli typu wymiany uzębienia obserwowanej u większości dzisiejszych ssaków (dwie generacje zębów: mleczne i stałe).

\section{TYPY WYMIANY ZEBBÓW U SSAKÓW MEZOZOICZNYCH}

Ssaki pojawiły się około 220 milionów lat temu w późnym triasie. Za najwcześniejszego przedstawiciela tej grupy uważany jest Sinoconodon rigneyi (CROMPTON i LUO 1993, KEMP 2005). Historia ewolucyjna ssaków w mezozoiku stanowi około $155 \mathrm{mln}$ (z 185 mln) lat jego trwania, czyli ponad $80 \%$ tej ery (KIELAN-JAWOROWSKA i współaut. 2004). Można więc śmiało twierdzić, iż w triasie, jurze i kredzie zaszły kluczowe etapy ewolucji wymiany zębów u ssaków. W ciagu milionów lat, odkąd ssaki zaczęły ewoluować, pojawiły się stopniowo różnorodne wzory i specjalizacje uzębienia, oraz schematy wyrzynania się i wymiany zębów.

\section{SINOKONODONTY (SINOCONODONTIDAE)}

Sinokonodonty należały do rodziny Sinoconodontidae, zawierajacej tylko jeden gatunek Sinoconodon rigneyi (Ryc. 1) o znacznym zróżnicowaniu morfologicznym. Zwierzęta te były najprawdopodobniej drapieżne, żywiąc się owadami lub innymi bezkregowcami, ewentualnie polowały na inne kręgowce; żyły we wczesnej jurze (synemur), pomiędzy 202 a 195 milionów lat temu. Szeroki zakres masy sinokonodona, od 13 g do 517 g, wskazuje, że rósł on przez większość życia (KIELAN-JAWOROWSKA i współaut. 2004). Jego czaszka powiększała się stale, co upodabniało go do gadów, także pod względem sposobu wymiany uzębienia. Proces wymiany uzębienia u sinokonodontów charakteryzuje się mieszanina cech plezjomorficznych (a stą nieinformatywnych dla odtwarzania filogenezy) i apomorficznych. Zęby przednie, siekacze i kły były wymieniane wiele razy, co jest cecha gadzią, występująca również u przodków sinokonodontów, gadów ssakokształtnych $z$ grupy cynodontów. Cechami zawansowanymi, które zbliżają sinokonodonty do 


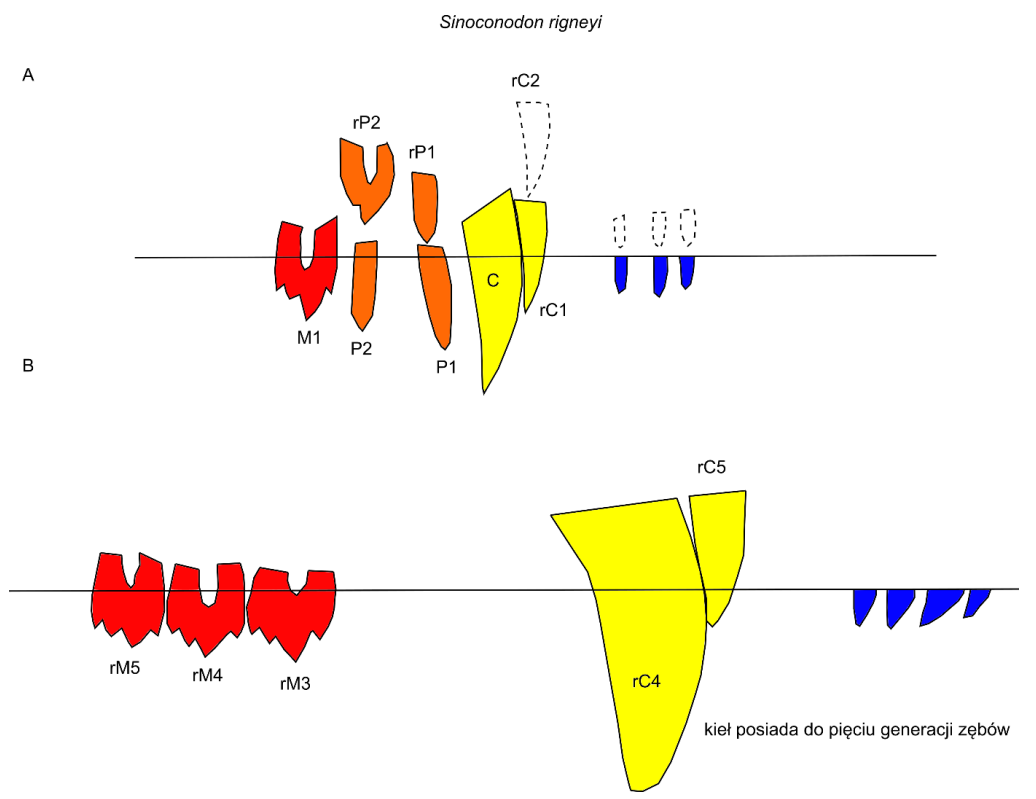

Ryc.1. Wymiana górnego uzębienia u Sinoconodon rigneyi. A. Osobnik młodociany. B. Starszy osobnik (Luo i współaut. 2004, zmieniona).

ssaków, jest zróżnicowanie zębów zakłowych na przedtrzonowe i trzonowe (LuO i współaut. 2004). Dorosłe osobniki miały duża diastemę między trzecim trzonowcem a kłem (LuO i współaut. 2004 fig. 2A, B) (Ryc. 1). Spowodowane było to przez stopniowa utratę zębów przedtrzonowych, które $z$ mlecznych zastępowane były stałymi, wypadajacymi następnie u starszych osobników. Podobnie tracone były przednie zęby trzonowe (M1-M2), co jeszcze przyczyniało się do powiększania diastemy. Tylne zęby trzonowe w szczęce (M3-M5) były wymieniane tylko raz. Funkcjonalne zęby trzonowe, wskutek powstania diastemy, były przesunięte ku tyłowi, co obserwuje się również u cynodontów, takich jak Thrinaxodon czy Probainognathus. Sekwencja wyrzynania się zębów przedtrzonowych i trzonowych była przednio-tylna, zaczynając od P1 a kończac na M5 (ZHANG i współaut. 1998, Luo i współaut. 2004).

\section{MORGANUKODONTY (MORGANUCODONTA)}

Morganucodon jest najbardziej znanym rodzajem rodziny Morganucodontidae. Był to owadożerny ssak żyjący w późnym triasie (noryk), około 220-210 mln lat temu. Wzór zębowy Morganucodon oehleri to: I4/ $\mathrm{i} 4$ - C1/c1 - P4/p5 - M3/m3-4 (KIELAN-JAWOROWSKA i współaut. 2004). Morganucodon miał o wiele mniejszy zakres masy ciała niż sinokonodon, a szacowany ciężar wahał się pomiędzy 27 a 89 g, co wskazuje, że także rozmiary czaszki tego zwierzeccia nie miały dużej rozpiętości. W związku $z$ tym nie zachodziła konieczność wielokrotnej wymiany zębów na nowe, proporcjonalnie większe w stosunku do stale powiększającej się czaszki (LuO i współaut. 2004).

Siekacze i kły miały dwie generacje, co jest cecha apomorficzna (nowa) w stosunku do sinokonodontów, które wykazywały, jak wspomniano, w obrębie kłów i siekaczy polifiodontyzm. Morganucodon miał jedno pokolenie stałych zębów przedtrzonowych, w zwiąku $z$ tym ten locus wymieniany był tylko raz. Trzonowce nie były wymieniane i stanowiły część stałego uzębienia. Sekwencja wymiany zębów przedtrzonowych postępuje w kierunku przednio-tylnym, podobnie jak u sinokonodona (LuO i współaut. 2004). Morganucodon jest jednym $z$ pierwszych ssaków, u których najprawdopodobniej występowała całkowita difiodoncja.

\section{EUTRYKONODONTY (EUTRICONODONTA)}

Eutrykonodonty były mięsożernymi ssakami o dużym zakresie rozmiarów ciała, od niewielkiego Jeholodens po takie rodzaje, jak Gobiconodon czy Repenomamus, będące jednymi $z$ największych ssaków ery mezozoicznej (Hu i współaut. 2005). Gobiconodon żył we wczesnej kredzie (walanżyn do albu) pomiecdzy 137 a $99 \mathrm{mln}$ lat temu (KIELAN-JAWOROWSKA i współaut. 2004).

Gobiconodon ostromi miał w połówce żuchwy pojedynczy siekacz, jeden kieł i cztery przedtrzonowce (Ryc. 2) (JENKINS i ScHAFF 1988), natomiast w szczęce trzy siekacze, kieł i dwa przedtrzonowce. LOPATIN i AVERIANOV (2015) sugerują, że gobikonodon miał taki sam wzór uzębienia w żuchwie jak i w szczęce, czyli trzy siekacze, kieł i dwa przedtrzonowce. Zęby trzonowe u gobikonodontów 

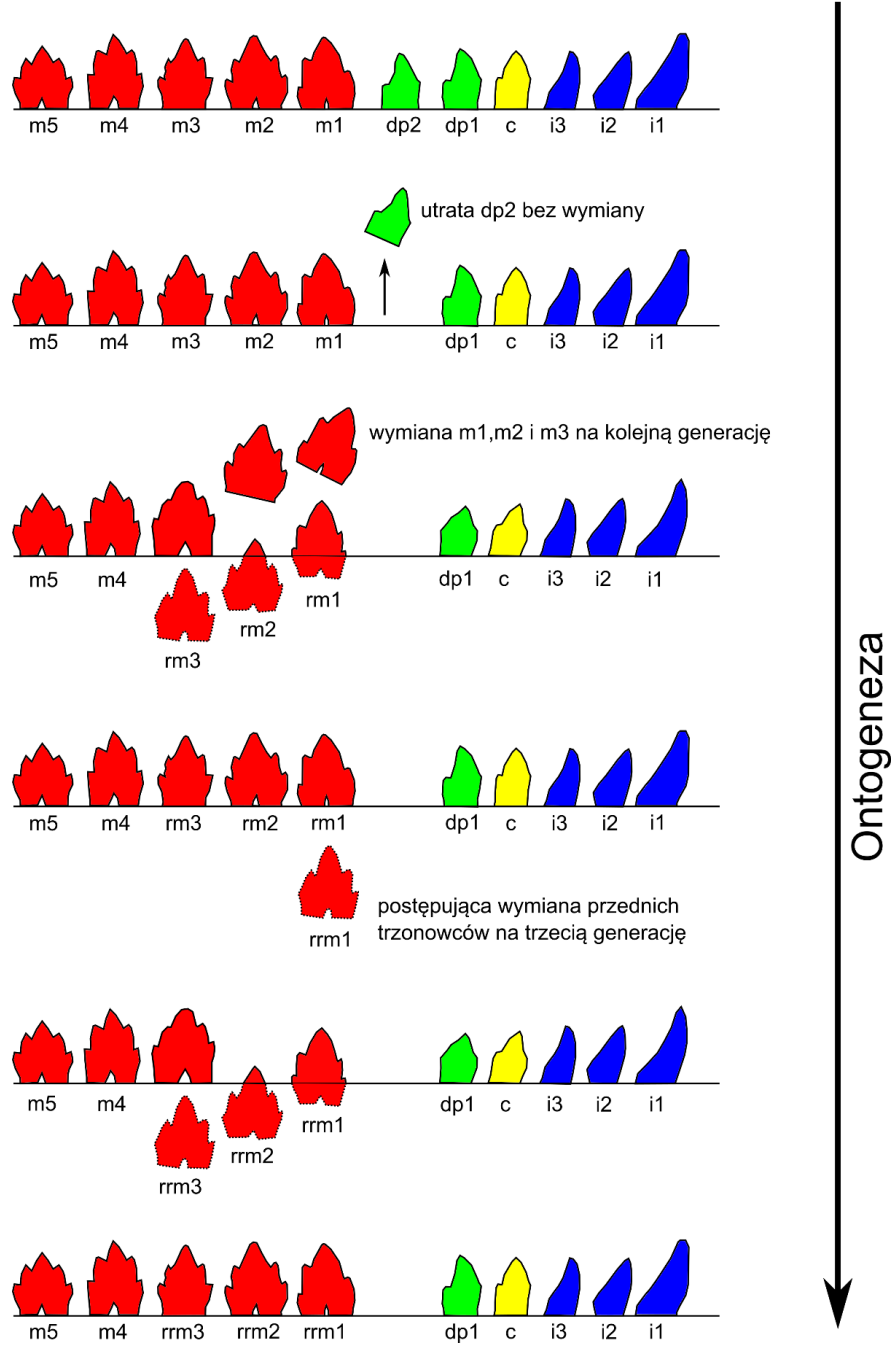

Ryc. 2. Wymiana uzębienia w prawej żuchwie Gobiconodon ostromi (LuO i współaut. 2004, zmieniona).

były wymieniane, co jest niespotykane wśród dzisiejszych ssaków i jest charakterystyczne dla całej tej grupy (KIELAN-JAWOROWSKA i współaut. 2004). Zęby trzonowe nowoczesnych ssaków należą do pokolenia zębów stałych i nie sa wymieniane na nowe. Luo i współaut. (2004) zaznaczają, że zęby znajdujące się za kłem, a podlegające wymianie, sa uznawane za przedtrzonowce, a nie za trzonowce. Jednak silniej wyrażona molaryzacja ostatnich pięciu zębów w rzędzie zębowym gobikonodontów sprawia, że różnią się one od przedtrzonowców, wskazujac tym samym, że zęby te były raczej trzonowcami. G. ostromi wymieniał pierwsze trzy dolne trzonowce (m1-m3); zęby te były dwukrotnie wymieniane, co daje ostatecznie, łącznie $z$ pokoleniem zębów mlecznych, aż trzy generacje. Pozostałe zęby trzonowe, m4 i m5, były częścia stałego uzębienia, tak jak u wspó1czesnych ssaków (Ryc. 2). U G. hoburensis następowała tylko jednokrotna wymiana zę- bowa trzonowców m1-m4 na nowe, co daje w sumie dwie generacje zębów trzonowych. $G$. borissiaki cechował się, podobnie jak $G$. ostromi, dwukrotna wymiana trzonowców, ale $\mathrm{w}$ porównaniu $\mathrm{z}$ tym ostatnim, najpierw wymieniał $\mathrm{m} 1-\mathrm{m} 5$, a drugiej wymianie podlegały już tylko m1-m2. Ta cecha wielokrotnej wymiany trzonowców mogła spowodować, że gatunki $z$ rodzaju Gobiconodon osiagnęły rozmiary dużo większe $\mathrm{w}$ porównaniu $\mathrm{Z}$ innymi mezozoicznymi ssakami, a co za tym idzie, mogły żywić się większymi ofiarami (LOPATIN i AVERIANOV 2015). Być może zęby trzonowe gobikonodona zużywały się, a zwierzęta nie potrafiły odnowić ich powierzchni tracej, tak jak to robia dzisiejsze gatunki ssaków drapieżnych w przypadku zębów zwanych łamaczami (KIELAN-JAWOROWSKA i współaut. 2004). W zwiazku $z$ tym, wymiana tych zębów w trakcie życia osobnika na nowe była niezbędna, aczkolwiek odrębna adaptacja, pozwalajaca gobikonodontom za- 
chować powierzchnię tnąca poprzez wymianę „zużytych” zębów. Jeśli faktycznie tak było, znaczyłoby to, iż gobikonodonty mogły, tak jak dzisiejsze ssaki drapieżne, kruszyć kości swoich ofiar i, cytujac KIELAN-JAWOROWSKA i współaut. (2004: 232) „dlatego mieć dostęp do składników odżywczych, które były niedostępne dla innych ssaków mezozoicznych". W rodzinie Gobiconodontidae wystepowały również gatunki niewielkich rozmiarów, jak Spinolestes xenarthrosus, ważacy od 52 do 72 g, który również wymieniał trzonowce (MARTIN i współaut. 2015). Zapewne również u spinolestesa wymiana trzonowców była adaptacja ułatwiająca odnowę powierzchni trącej zębów.

W rzędzie Eutriconodonta obserwuje się znaczną różnorodność pod względem typów wymiany uzębienia (KIELAN-JAWOROWSKA i współaut. 2004). Badania wskazują, że rodzaj Acinacodus, będacy przedstawicielem amfidontidów, jak i bazalny trechnoter, Kiyatherium, mogły mieć podobna jak gobikonodonty wymianę trzonowców (LOPATIN i AVERIANOV 2015). Ponadto, Repenomamus, największy przedstawiciel rodziny Gobiconodontidae (czaszka miała ponad $10 \mathrm{~cm}$ długości), będący równocześnie jednym $z$ największych ssaków ery mezozoicznej, cechował się polifiodontyzmem siekaczy i kłów, co upodobniało go zarówno do sinokonodona, jak i cynodontów (KIELAN-JAWOROWSKA i współaut. 2004).

\section{HARAMIYIDY (HARAMIYIDA)}

Haramiyida były jedna $z$ wcześniejszych grup ssaków, znana już w późnym triasie i szeroko rozpowszechniona w jurze. Zwierzęta te były najprawdopodobniej roślinożerne lub wszystkożerne (LUO i współaut. 2015). Większość $z$ nich nie miało kłów, ponadto cechowały się znaczna redukcją zębów. Ostatnie badania MAO i współaut. (2019) znacznie poszerzyły wiedzę na temat wymiany uzębienia w tej zagadkowej grupie ssaków, uważanej niekiedy za blisko spokrewniona $z$ wieloguzkowcami (Multituberculata).

Jednym $Z$ przedstawicieli haramiyidów jest Arboroharamiya jenkinsi, charakteryzujaca się wzorem uzębienia: $\mathrm{I} 1 / \mathrm{i} 1$ - $\mathrm{CO} / \mathrm{c0}-\mathrm{P}$ 2/p1 - M2/m2. Dorosłe zwierze odznaczało się znaczna redukcja liczby siekaczy, mając tylko jeden po każdej stronie żuchwy i szczęki. Górny siekacz to stały zab drugiej pary (I2), natomiast dolny siekacz to i1, czyli stały siekacz pierwszej pary. Brak kłów u $A$. jenkinsi jest również charakterystyczny dla większości haramiyidów. Nastapiła u nich również redukcja przedtrzonowców. A. jenkinsi nie miała w uzębieniu pierwszych dwóch górnych przedtrzonowców (P1 i P2), ale miała P3 i P4. W żuchwie redukcja przedtrzo- nowców była znaczna, ponieważ obecny był jedynie przedtrzonowiec p4. Arboroharamiya miała nieliczne trzonowce zarówno w szczęce, jak i żuchwie, gdyż obecne były tylko M1/ $\mathrm{m} 1$ i M2/m2. Prawdopodobnie jako pierwszy $z$ przedtrzonowców mógł wyrzynać się P4, a następnie P3; wskazuje na to większy stopień starcia zęba P4 w stosunku do P3 w badanym okazie, co sugeruje, iż P4 był już wykorzystywany do żucia pokarmu jako w pełni funkcjonalny ząb, podczas gdy P3 dopiero się wyrzynał (MAO i współaut. 2019). Z badań paleontologicznych wynika, że A. jenkinsi wykazywała difiodoncje, czyli dwie generacje siekaczy, przedtrzonowców, a pojedynczą generację trzonowców (MAO i współaut. 2019), podobnie jak współczesne ssaki.

\section{WIELOGUZKOWCE (MULTITUBERCULATA)}

Wieloguzkowce to jedna $z$ najdłużej $\dot{z} y-$ jących grup ssaków; w zapisie kopalnym znane sa od jury do końca eocenu, czyli występowały na Ziemi ponad 125 milionów lat. Wieloguzkowce były najprawdopodobniej roślinożerne lub wszystkożerne, a ich zęby, jak nazwa wskazuje, cechowała obecność licznych drobnych guzków na powierzchni zwarciowej. Wśród wieloguzkowców wyróżnia się dwie podstawowe grupy różniące się wzorem zębowym. Pierwsza to Plagiaulacida, charakteryzująca się pięcioma górnymi przedtrzonowcami. Druga grupa, Cimolodonta, miała od jednego do czterech przedtrzonowców (KIELAN-JAwOROWSKA i współaut. 2004). Wieloguzkowce najprawdopodobniej wykazywały difiodoncję. Siekacze, kły i przedtrzonowce występowały w dwóch generacjach, natomiast trzonowce były częścią zębów stałych. Sugeruje się, iż rodzaj Kielanodonz linii Paulchoffatiida wymieniał przedtrzonowce w sekwencji tylno-przedniej, jak u prymitywnych gadów ssakokształtnych, takich jak Thrinaxodon. Natomiast wczesnopaleogeński Taeniolabis z Ameryki Północnej wykazywał już przednio-tylna sekwencje wymiany. Kwestia dyskusyjna jest, czy przednio- tylna sekwencja była rozpowszechniona tylko u północnoamerykańskich gatunków $z$ paleogenu, czy może też u pozostałych wieloguzkowców, a tylno-przednia sekwencja wymiany jest charakterystyczna tylko dla linii Paulchoffatiida (LuO i współaut. 2004).

Jednym $z$ przedstawicieli grupy Cimolodonta jest Catopsbaatar catopsaloides, znany z późnej kredy (późny kampan, ok. $75 \mathrm{mln}$ lat temu). W odróżnieniu od innych wieloguzkowcówz podrzędu Cimolodonta miał on trzy przedtrzonowce, zamiast czterech. (KIELAN-JAWOROWSKA i współaut. 2004). 
W wymianie zębów u multituberkulatów jako pierwszy stały ząb przedtrzonowy w szczęce wyrzynał się P4, następnie P1 i P3, a na końcu P2. W przypadku siekaczy stałych najpierw wyrzynal się I2 a następnie I3.

\section{METATHERIA I EUTHERIA}

Eutery jest to grupa, do której należa dzisiejsze łożyskowce, natomiast druga grupa sa metatery, obejmujace torbacze, a kilka cech uzębienia łączy obie te grupy. Ich zęby sa zróżnicowane na cztery typy: siekacze, kły, przedtrzonowce i trzonowce, przy czym te ostatnie rosna jako część stałego uzębienia. Już na wczesnym etapie ewolucji tych grup, wymiana uzębienia była ograniczona do dwóch generacji, czyli difiodoncji. Jednak największe zmiany, prowadzace do monofiodontyzmu, widoczne sa u torbaczy.

\section{PIERWOTNE I WSPÓŁCZESNE SSAKI NIŻSZE (METATHERIA)}

Alphadon to prymitywny torbacz żyjacy w późnej kredzie Ameryki Płn. (CIFELLI i współaut. 1996). W żuchwie dorosłego alfadona znajdowały się trzy mleczne siekacze (di1-di3), mleczny kieł i trzy przedtrzonowce, $z$ których dwa pierwsze były zębami mlecznymi i nie były wymieniane (dp1-dp2), a trzeci to ząb, który u młodych osobników był zastępowany stałym przedtrzonowcem. Alphadon mial cztery trzonowce, przy czym jako ostatni $z$ trzonowców wyrzynał się m4 (Ryc. 3) (LuO i współaut. 2004). Podobnie jak u współczesnych torbaczy, wymieniany był tylko trzeci przedtrzonowiec (oraz sposób wymiany zębów, identyczne $z$ charakterystycznymi dla dzisiejszych torbaczy), co sugeruje, że Alphadon mógł być bliskim krewnym współczesnych torbaczy (CIFELLI i

Kulbeckia kulbecke
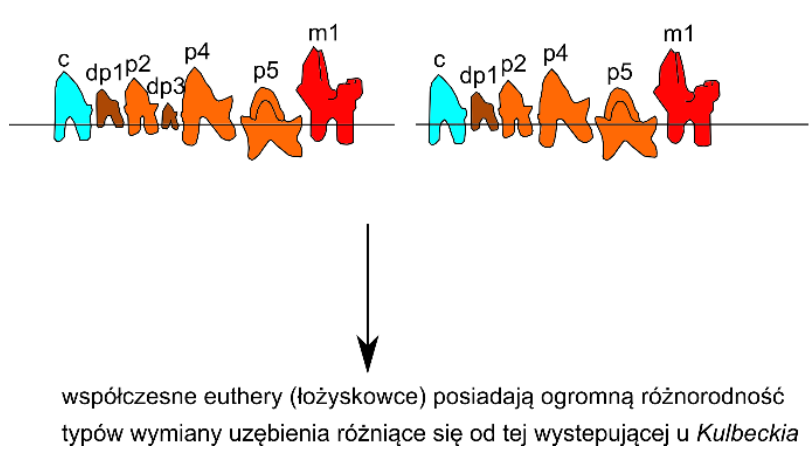

współaut. 1996). Co więcej, u dzisiejszych torbaczy taka wymiana uzębienia jest ściśle związana $z$ wczesnym rozwojem, tzn. faktem, że młode bardzo szybko i na długo przytwierdza się do sutka matki (NowAK 1991). Może to wskazywać, iż już Alphadon mógł charakteryzować się typowym dla torbaczy sposobem rozrodu (CIFELLI i współaut. 1996). Wszyscy współcześni przedstawiciele Metatheria należa do kohorty torbaczy. Sa one znacznie mniej liczne niż współczesne ssaki łożyskowe. Torbacze, w przeciwieństwie do łożyskowców, mają od siedmiu do ośmiu zębów zakłowych, w zależności od gatunku. Wszystkie gatunki maja trzy przedtrzonowce i od czterech do pięciu trzonowców (NOWAK 1991). Cecha charakterystyczna współczesnych torbaczy jest wyrzynanie się tylko trzeciego zęba stałego P3, reszta zębów nie jest wymieniana na zęby stałe, natomiast trzonowce pojawiaja się jako część stałego uzębienia (CifELli i współaut. 1996). Dydelf wirginijski (Didelphis virginiana) jest jednym $z$ największych oposów, żyjącym obecnie w Ameryce Północnej. Waży od 2 do $5,5 \mathrm{~kg}$. Prowadzi nocny tryb życia. Wzór uzębienia dydelfa to: I5/i4 - C1/c1 - P3/p3 - M4/ m4 (NOWAK 1991). W żuchwie ma on cztery mleczne siekacze, co odróżnia go od kredowego alfadona, który miał w żuchwie tylko trzy siekacze.

\section{PRYMITYWNE EUTHERIA}

Kulbeckia kulbecke to prymitywny ssak łożyskowy, który w późnej kredzie żył na terenach dzisiejszego Uzbekistanu (AVERIANOV i ARCHIBALD 2015). Mogła ona mieć trzy, cztery lub nawet pięć górnych siekaczy i cztery dolne (Ryc. 3) (WiBle i współaut. 2004). Ponadto, zwierzę miało od czterech do pięciu przedtrzonowców. Pierwszy przedtrzonowiec $K$. kulbecke był zębem mlecznym i nigdy nie ulegał wymianie na ząb stały. Kieł, podob-

Alphadon

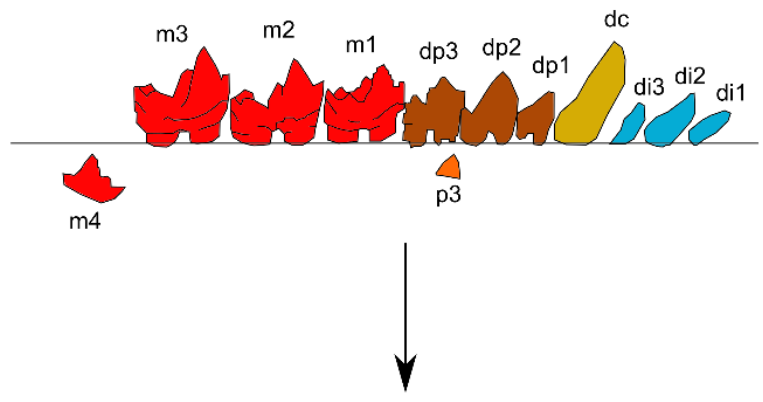

współczesne metathery (torbacze) posiadają identyczną wymianę uzebienia jak Alphadon

Ryc. 3. Porównanie uzębienia Kulbeckia i Alphadon. 
nie jak drugi przedtrzonowiec, wyrzynał się w tym samym czasie. Jako ostatni w żuchwie wyrzynał się przedtrzonowiec p5. Z przedtrzonowców tylko P2/p2, P4/p4, P5/p5 miały dwie generacje zębów. U większości okazów $K$. kulbecke obecne były tylko cztery przedtrzonowce, ponieważ mleczny ząb dP3/dp3 ulegał najczęściej wchłonięciu i nie wyrzynał się. Natomiast jeśli u młodszych osobników powstawała diastema między P2/ p2 a P4/p4, i w tej przestrzeni wyrzynał się ząb mleczny dP3/dp3, który nigdy nie był wymieniany na stały trzeci przedtrzonowiec, powodowało to chwilowe zwiększenie liczby przedtrzonowców do pięciu. Takie efemeryczne pojawianie się dP3/dp3 nie jest typowe jedynie dla kulbekii, ale obserwuje się je również u wielu innych prymitywnych euterów. Jeden $z$ najprymitywniejszych euterów, jurajska Eomaia scansoria, miała zarówno $\mathrm{dP} 3 / \mathrm{dp} 3$, jak i P3/p3 w uzębieniu. Inne gatunki, jak Bobolestes zenge czy Maelestes gobiensis, również miały $\mathrm{dP} 3 / \mathrm{dp} 3$, ale już o zredukowanej wielkości. Najprawdopodobniej utrata dP3/dp3 następowała niezależnie w wielu liniach, a $K$. kulbecke, podobnie jak Kennalestes gobiensis, sa przykładami gatunków, u których zaznaczała się pewna zmienność osobnicza pod względem tej ce- chy (osobniki $z$ dp3 i bez) (AVERIANOV i ARCHIBALD 2015). AVERIANOV i ARCHIBALD (2015) wysuwaja hipotezę, iż wspólny przodek wszystkich ssaków łożyskowych posiadał ząb mleczny dP3/dp3, zaś utrata tego locus jest synapomorfia tej grupy.

\section{WSPÓŁCZESNE ŁOŻYSKOWCE}

Wszystkie współczesne eutery należą do ssaków łożyskowych (Placentalia) (NowAK 1991, KIELAN-JAWOROWSKA i współaut. 2004, KEMP 2005). Jest to grupa, która osiagnęła bardzo duży sukces ewolucyjny, jej przedstawiciele żyja na wszystkich kontynentach i zamieszkuja prawie wszystkie środowiska, włączając oceany, pustynie czy mroźne tereny podbiegunowe. Ssaki łożyskowe cechuje również ogromna różnorodności form, od niewielkich gryzoni czy nietoperzy, po olbrzymie gatunki wodne, takie jak płetwal błękitny, czy lądowe, jak np. słoń afrykański. Ta duża zdolność przystosowawcza współczesnych ssaków ma odzwierciedlenie w różnorodnych wzorach zębowych i schematach wymiany uzębienia.

Wśród współczesnych łożyskowców wyróżniamy cztery zasadnicze klady: Afrotheria,

Potamogale velox
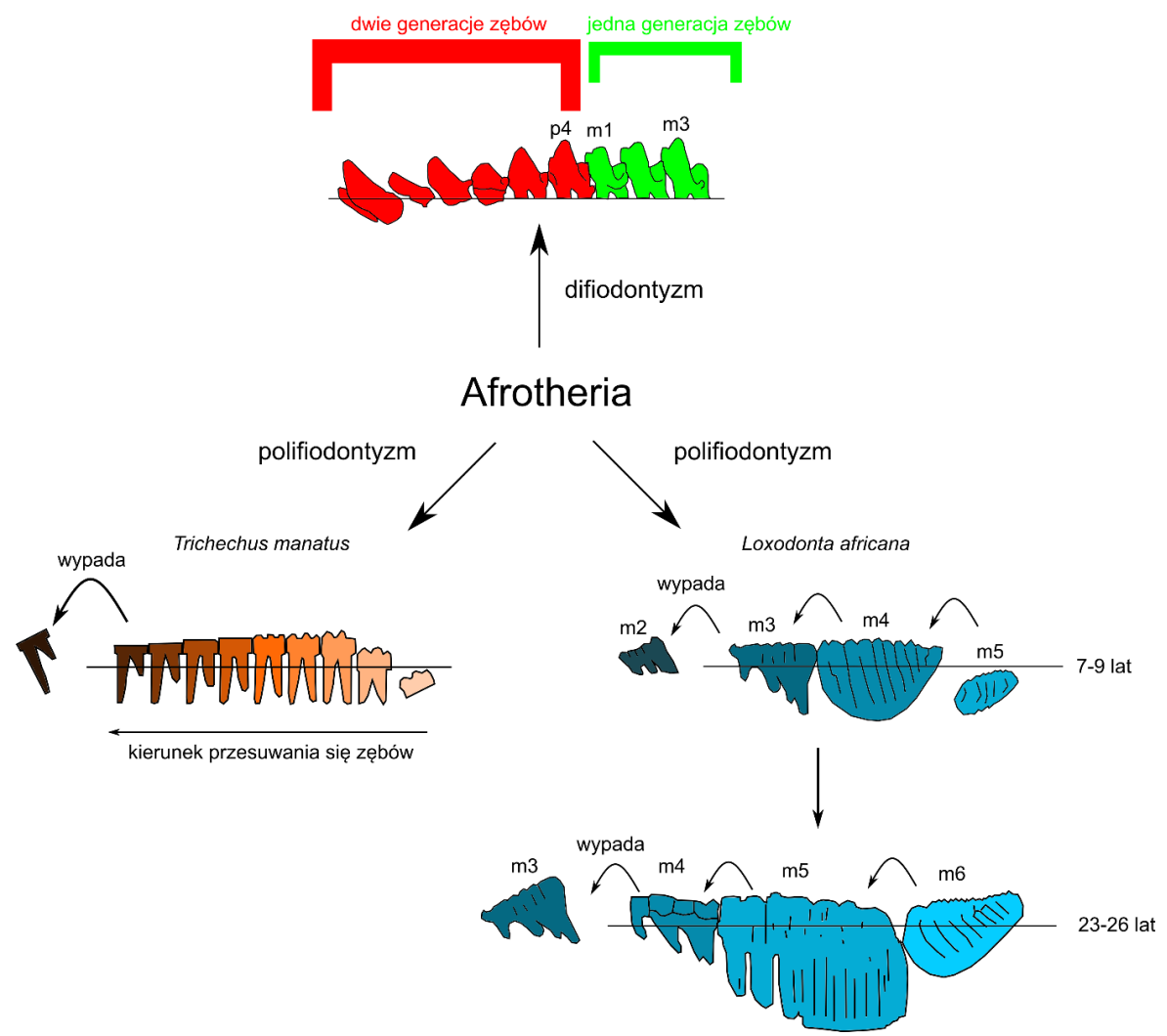

Ryc. 4. Porównanie różnych typów uzębienia w grupie afrotheria (SzARSKI 1978, RodRIGUES i współaut. 2011, BROCKLEHURST i współaut. 2016) 
Xenarthra, Laurasiatheria i Euarchontoglires.

Afrotheria to grupa ssaków obejmujaca bardzo różnorodne gatunki zwierząt występujących na kontynencie afrykańskim i połaczone pokrewieństwami genetycznymi. Cechą charakterystyczna afroterów jest wymiana zębów mlecznych na stałe później niż $\mathrm{u}$ innych ssaków. U dorosłych afrotherów, takich jak syreny czy słonie, wyrzynanie się zębów stałych jest dość powszechne po osiagnięciu dojrzałości płciowej, natomiast u małych afroterów, w tym u tenreka, nie jest to do końca jasne (ASHER i LEHMANN 2008). Z badań ASHERA i LEHMANNA (2008) wynika, że również małe afrotery wymieniały zęby mleczne na stałe później, niż inne ssaki nienależące do grupy Afrotheria. Jednym $z$ przedstawicieli afrotherów jest manat (Trichechus manatus) należący do rzędu syrenowatych, który ma w znacznym stopniu zredukowane uzębienie. Dorosłe manaty nie maja siekaczy i kłów, natomiast aż do dziesięciu zębów zakłowych (NowAK 1991). Ta znaczna liczba trzonowców wyrzyna się stopniowo przez całe życie manatów (Ryc. 4) (AsHeR i LEHMANN 2008), co może mieć zwiazek $z$ pobieraniem pożywienia $z$ dna morskiego, razem z piaskiem (NowAK 1991), co powoduje szybkie ścieranie się zębów. Podobnie wielokrotna wymiana zębów występuje u słonia afrykańskiego (Loxodonta) (Ryc. 4), gdzie przednie trzonowce po pewnym czasie wypadaja, a w tylnej części żuchwy wyrzynaja się nowe zeby (SZARSKI 1978).

Xenarthra to rząd obejmujący współcześnie 30 gatunków zwierzat reprezentujących grupy takie jak: pancerniki, leniwce i mrówkojady. Przedstawiciele tego rzędu nie maja siekaczy i kłów, które uległy całkowitej redukcji. Z drugiej strony, niektóre pancerniki mają tak liczne zęby policzkowe, że zalicza się je do zwierząt o największej liczbie zębów wśród ssaków. Mrówkojady, jak np. mrówkojad wielki (Myrmecophaga tridactyla), sa bezzębnymi przedstawicielami szczerbaków. Żywia się mrówkami i termitami, które chwytaja za pomoca długiego, lepkiego jezzyka (NOWAK 1991). Najprawdopodobniej dieta mrówkojadów sprawiła, że $\mathrm{w}$ trakcie ewolucji utraciły wszystkie zęby.

Laurasiatheria jest to klad obejmujacy między innymi Eulipotyphla obejmujący: jeżowate (Erinaceidae), ryjówkowate (Soricidae), almikowate (Soelnodontidae) i kretowate (Talpidae). Ponadto do tego kladu należa Cetartiodactyla, do których zaliczamy m.in. walenie (Cetacea) i przeżuwacze (Ruminantia). W skład Laurasiatheria wchodza również nietoperze (Chiroptera), nieparzystokopytne (Perissodactyla), łuskowce (Pholidota) i drapieżne (Carnivora). U ryjówek zęby mlecz- ne tracone sa przed urodzeniem, stad maja one tylko jeden zestaw, zęby stałe (monofiodontyzm). Fiszbinowce (Mysticeti), należace do waleni, nie maja zębów, zamiast nich sa fiszbiny, które służa im do pobierania pokarmu. Zębowce (Odontoceti) maja duża liczbę identycznych zębów, a więc występuje $\mathrm{u}$ nich homodontyzm. $Z$ kolei łuskowce (Pholidota) w ogóle nie maja zębów, podobnie jak mrówkojady (SzARSKI 1978). Do rzę$\mathrm{du}$ drapieżnych (Carnivora) należy siedem rodzin, w tym: kotowate, psowate i niedźwiedziowate. Obecnie żyje ok. 240 gatunków drapieżnych. $Z$ badań wynika, że rzad drapieżnych powstał niezależnie od owadożernych i że pierwsze drapieżne pojawiły się w późnym paleocenie (NOWAK 1991, KeMP 2005, BENTON 2015). Jedna $z$ ważnych cech charakterystycznych dla ssaków drapieżnych sa łamacze, czyli przekształcone P4 i m1, działające w zwarciu jak nożyce.

Do grupy Euarchontoglires należa m.in. gryzonie, zajęczaki, wiewióreczniki i naczelne. Gryzonie to najliczniejszy rząd, głównie niewielkich ssaków, współcześnie skupionych w ok. 30 rodzinach. Siekacze gryzoni należa do pokolenia zębów mlecznych (formalnie drugiej pary, dI2/di2) (Ryc. 5), które rosna przez całe życie i nigdy nie sa wymieniane. U niektórych gatunków gryzoni trzonowce również moga rosnąc przez całe życie zwierzęcia. Gryzonie, z większości rodzin, posiadaja tylko jeden przedtrzonowiec (czwarty, dP4/dp4) i tylko ten wymieniaja. Jedna $z$ najliczniejszych rodzin gryzoni sa myszowate (Muridae) (NowAK 1991), których wzór zębowy to: I1/i1 - C0/ $\mathrm{c0}-\mathrm{PO} / \mathrm{pO}-\mathrm{M} 3 / \mathrm{m} 3$. Myszowate sa całkowicie pozbawione przedtrzonowców, w zwiąku $z$ tym nie ma u nich wymiany uzębienia. Trzonowce rosna jako zęby stałe. To oznacza, że $\mathrm{u}$ gryzoni $\mathrm{z}$ rodziny myszowatych doszło do całkowitego monofiodontyzmu, czyli występowania wyłącznie jednej generacji zębów w szczęce i żuchwie. Ciekawym przypadkiem wśród gryzoni jest kretoszczurek srebrzysty, Heliophobius argenteocinereus. Gatunek ten, przez to, że spożywa pokarm razem $z$ gleba, ma duże zużycie zębów policzkowych. Sukcesywnie wyrzynające się zęby $\mathrm{w}$ tylnej części szczęki stopniowo przesuwaja się ku przodowi, wymieniając bardziej zużyte zęby przednie (RoDRIGUES i współaut. 2011). Kolejnym rzędem ssaków należącym do grupy Euarchontoglires sa zajęczaki (Lagomorpha). Rząd ten jest blisko spokrewniony $z$ rzędem gryzoni i obejmuje ok. 80 gatunków (NOWAK 1991, WILSON i współaut. 2016). Jedną z ważnych cech jaka odróżnia zajęczaki od gryzoni, jest ich wzór zebowy. Ogólna formuła zębowa dla rodziny zajacowatych (Leporidae) to: I2/i1 $\mathrm{CO} / \mathrm{c} 0$ - P3/p2- M3/m3. W porównaniu z rodziną myszowatych, już na poczatku moż- 
Otolemur garnetti (naczelne)

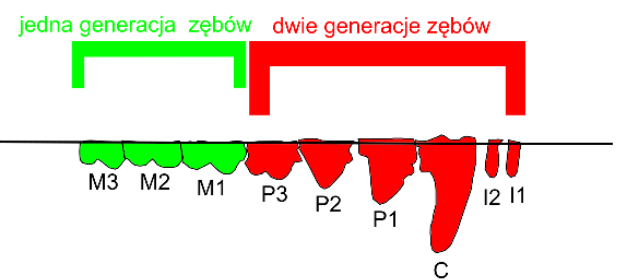

Rodzina zającowate (Leporidae) Oryctolagus cuniculus

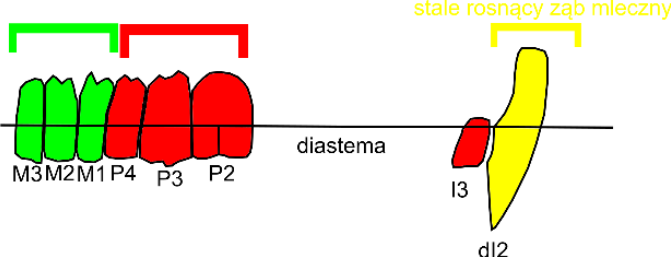
difiodontyzm difiodontyzm + monofiodontyzm

\section{Euarchontoglires}

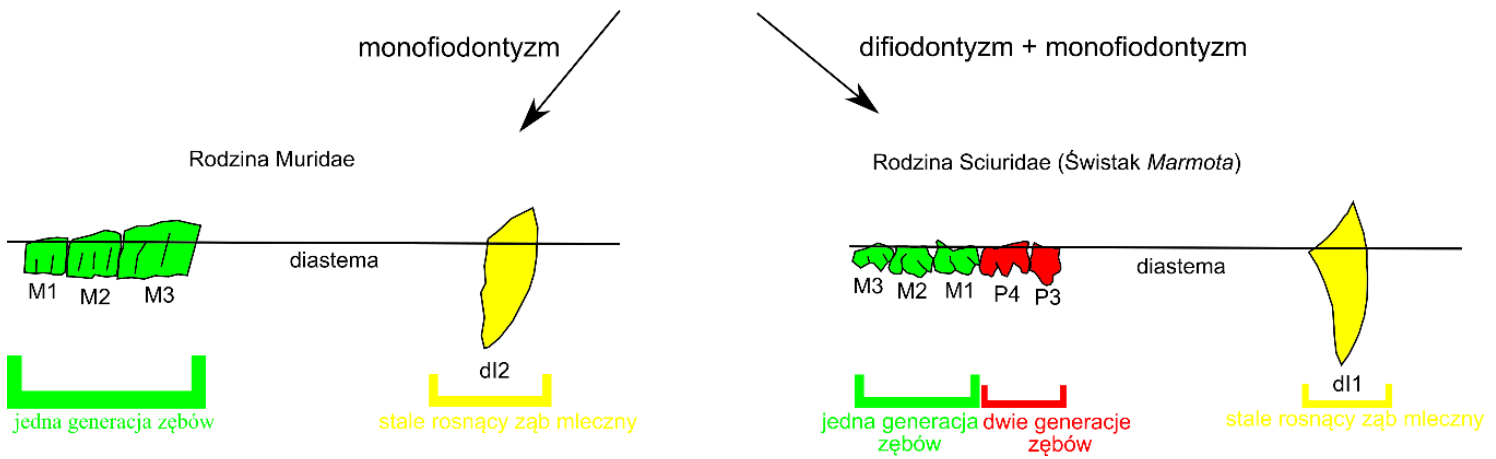

Ryc. 5. Porównanie różnych typów uzębienia w grupie Euarchontoglires (wg materiału $z$ IP PAN, NOwAK 1991).

na zauważyć różnice w liczbie siekaczy. Zajaccowate mają dwa górne siekacze i pojedynczy dolny, natomiast u gryzoni występuje po jednym górnym i dolnym siekaczu (REKOVETS 1985). W obu grupach ssaków brak kłów. Jedną $z$ największych różnic w stosunku do gryzoni jest liczba zębów przedtrzonowych. Jak wspomniano, rodzina myszowatych, nie ma zębów przedtrzonowych, natomiast inne rodziny, jak wiewiórkowate (Sciuridae), moga mieć od dwóch górnych do jednego przedtrzonowca dolnego. $\mathrm{Z}$ kolei zajęczaki maja trzy przedtrzonowce w szczęce (Ryc 5), a dwa w żuchwie. Zajęczaki maja taka sama liczbę zębów trzonowych jak u gryzoni, po trzy $z$ każdej strony w szczęce i w żuchwie. Ostatni rzad $z$ grupy Euarchontoglires omawiany $\mathrm{w}$ niniejszej pracy to rzacd naczelnych (Primates). Gatunków naczelnych jest ponad 300 (NowAK 1991). Jednym z przedstawicieli naczelnych jest Otolemur garnetti, który posiada wszystkie cztery typy zębów, co wyróżnia go od zajęczaków czy gryzoni (Ryc. 5). Do tego rzędu należy również człowiek (Homo sapiens), jeden $z$ najbardziej rozpowszechnionych gatunków ssaków na Ziemi.

\section{PODSUMOWANIE}

Ewolucja uzębienia u ssaków, przez 220 milionów lat przebiegała w kilku etapach, z których najbardziej charakterystyczny, czyli difiodoncja, pojawił się niemal na samym początku. U Morganucodon wystąpiły po raz pierwszy dwie generacje zębów, które dały podwaliny do następnych kroków w ewolucji. Jednak w rodzinie Gobiconodontidae u najwcześniejszych przedstawicieli wymiana pierwszych zębów trzonowych była powszechna, natomiast $z$ biegiem ewolucji, ssaki te utraciły tę prymitywna cechę na rzecz jednej stałej generacji trzonowców. Niewątpliwie drugim krokiem ku tylko dwóm generacjom uzębienia było zróżnicowanie się zębów na siekacze, kły, przedtrzonowce i trzonowce, które zaczęły spełniać konkretna funkcję, co miało miejsce w przypadku Sinoconodon i wspomnianym już Morganucodon. Odrębnym trendem, obserwowanym wśród współczesnych grup ssaków (włączając człowieka), jest postępująca redukcja uzębienia, szczególnie w grupie zębów trzonowych. Nie obserwuje się natomiast trendów zwiększania liczby zębów. Mimo tego, także obecnie występuja ssaki posiadajace (zapewne wtórna) polifiodoncję lub opóźnioną wymianę zębowa, często zachodzącą przez całe życie zwierzęcia, jak w przypadku słonia afrykańskiego i manata. Monofiodoncję, cechująca np. ryjówki czy myszy, można traktować jako krańcowy przykład przyspieszonej wymiany zębów.

Zmiany jakie zachodziły przez miliony lat ewolucji stały się podwalinami dla szerokiej 
gamy morfologicznej zębów oraz ogromnej różnorodności sekwencji wymiany uzębienia, którą możemy obserwować zarówno u dzisiejszych, jak i u wymarłych ssaków. Ostatnie lata badań nad ewolucją ssaków przynosza pełniejsza wiedzę na temat tego długiego procesu i pomagaja lepiej zrozumieć drogę, jaka przeszły ssaki przez ponad 220 milionów lat swej historii.

\section{PODZIEKOWANIA}

Pragnę wyrazić moją wdzięczność Pani dr hab. Łucji Fostowicz-Frelik z Instytutu Paleobiologii PAN im. Romana Kozłowskiego za merytoryczna pomoc oraz wskazówki przydatne podczas pisania tej pracy.

\section{Streszczenie}

Wymiana uzębienia $\mathrm{u}$ ssaków to jeden $\mathrm{z}$ najważniejszych procesów ewolucyjnych w tej grupie kręgowców. Pierwsze ssaki wykazywały dużo cech pierwotnych, odziedziczonych po gadzich przodkach. Już na bardzo wczesnym etapie zęby zróżnicowały się na siekacze, kły, przedtrzonowce i trzonowce, pojawiła się też tendencja do redukcji liczby zębów. Przełomowe znaczenie miało powstanie difiodoncji, czyli występowania dwóch pokoleń zębów, mlecznych i stałych, co jest charakterystyczna cechą ssaków, w odróżnieniu od polifiodontycznych gadów. Ewolucja wymiany uzębienia szła w kierunku coraz mniejszej liczby wymienianych zębów. Celem niniejszego artykułu jest przybliżenie Czytelnikom głównych etapów zapoczatkowanego przed ponad $200 \mathrm{mln}$ lat procesu, który doprowadził do znacznego zróżnicowania zarówno wzorów uzębienia, jak i typów wymiany zębów, co obserwujemy u współczesnych ssaków.

\section{LITERATURA}

ASHER R. J., LEHMANN T., 2008. Dental eruption in afrotherian mammals. BMC Biology 6, doi: 10.1186/1741-7007-6-14.

AvERIANOV A. O., ARCHIBALD J. D., 2015. Evolu tionary transition of dental formula in Late Cretaceous eutherian mammals. Sci. Nat. 102, doi: $10.1007 / \mathrm{s} 00114-015-1308-1$.

BENTON M. J., 2015. Vertebrate palaeontology. Wiley Blackwell, Oxford.

BROCKLEHURST R. J., CRUMPTON N., BuTTON E, ASHER R. J., 2016. Jaw anatomy of Potamogale velox (Tenrecidae, Afrotheria) with a focus on cranial arteries and the coronoid canal in mammals. PeerJ. 4, doi: 10.7717/peerj.1906.

CifElli R. L., ROWE T. B., LUCKETT P. W., BANTA J., Reyes R., Howes R. I., 1996. Fossil evidence for the origin of the marsupial pattern of tooth replacement. Nature 379, 715-718.

CROMPTON A. W., LUO Z., 1993. Relationships of the Liassic Mammals Sinoconodon, Morganucodonoehleri, and Dinnetherium. [W:] Mammal phylogeny. SZALAY F. S., NOVACEK M. J., MCKENNA M. C. (red.). Springer, New York, 30-44.
Hu Y., Meng J., WANG Y., Li C., 2005. Large Mesozoic mammals fed on young dinosaurs. Nature 433, 149-152.

JENKINS JR. F. A., SCHAFF C. R.,1988. The Early Cretaceous mammal Gobiconodon (Mammalia, Triconodonta) from the Cloverly Formation in Montana. J. Vertebr. Paleontol. 8, 1-24.

KEMP T. S., 2005. Origin and evolution of mammals. Oxford University Press, New York.

KIELAN-JAWOROWSKA Z., CIFELlI R. L., LUO Z., 2004. Mammals from the Age of Dinosaurs: origins, evolution and structure. Columbia University Press, New York.

Lopatin A. V., AVERIANOV A. O., 2015. Gobiconodon (Mammalia) from the Early Cretaceous of Mongolia and Revision of Gobiconodontidae. J. Mammalian Evol. 22, 17-43.

Luo Z., Gatesy S. M., Jenkins JR. F. A.,Amaral W. W., ShuBin N. H., 2015. Mandibular and dental characteristics of Late Triassic mammaliaformHaramiyavia and their ramifications for basal mammal evolution. Proc. Natl. Acad. Sci. USA 112, E7101-E7109.

Luo Z., Kielan-JaWorowska Z., CifElli R. L., 2004. Evolution of dental replacement in mammals. Bull. Carnegie Museum Nat. History 36, 159-175.

MAO F. Y., ZHENG X. T., WANG X. L., WAND Y.-Q., BI S.-D., MENG J., 2019. Evidence of diphyodonty and heterochrony for dental development in euharamiyidan mammals from Jurassic Yanliao Biota. Vertebrata PalAsiatica 57, 51-76.

MARTIN T., MARUGÁN-LOBÓN J., VULLO R., MARTÍNABad H., LuO Z., Buscalioni D. A., 2015. A Cretaceous eutriconodont and integument evolution in early mammals. Nature 526, 380384

NOWAK M. R., 1991. Walker's mammals of the world. Vol. 1, 2. Johns Hopkins University Press, Baltimore.

REKOVETS L. I. 1985. Microtheriofauna of the of Desna-Dnieper Late Paleolithic. Kiev, Naukova Dumka, 1-166 (po rosyjsku).

Rodrigues H. G; MARANGONI P., SUMBERA R., TAFFOREAU P., WENDELEN W., VIRIOT L., 2011. Continuous dental replacement in a hyper-chisel tooth digging rodent. Proc. Natl. Acad. Sci. USA 108, 17355-17359.

SZARSKI H., 1978. Anatomia porównawcza kręgowców. PWN, Warszawa.

SZARSKI H., 1998. Historia zwierzat kręgowych. PWN, Warszawa.

WeISHAMPEL D. B., DODSON P., OSMÓlSKA H., 2007. Dinosauria. University California Press, Oakland.

Wible J. R., NovaceK M. J., RougieR G. W., 2004. New data on the skull and dentition in the Mongolian late Cretaceous eutherian mammal Zalambdalestes. Bull. Am. Museum Nat. History 281, 1-144.

Wilson D. E., LACHER T. E., MitTERMEIER R. A., 2016. Handbook of the mammals of the world: lagomorphs and rodents. I. vol. 6. Lynx Editions, Barcelona.

ZHANG F., CROMPTON A. W., LuO Z., SCHAFF C. R., 1998. Pattern of dental replacement of Sinoconodon and its implications for evolution of mammals. Vertebrata PalAsiatica 36, 197 217. 
KOSMOS Vol. 70, 1, 83-93, 2021

\title{
PAWEe Muniak
}

Faculty of Biology, Jagiellonian University, 7 Gronostajowa Str., 30-387 Kraków, E-mail: pawel.muniak@student.uj.edu.pl

\author{
THE PROCESS OF DENTAL REPLACEMENT IN SELECTED GROUPS OF MAMMALS IN AN EVOLUTIONARY \\ APPROACH
}

\section{Summary}

Dental replacement in mammals is one of the most important evolutionary processes in these vertebrates. First mammals had many primitive features inherited from the reptilian ancestors. Already at a very early stage the teeth diversified into the incisors, canines, premolars, and molars. A tendency to reduce the tooth count also appeared. The groundbreaking innovation was the emergence of diphyodont replacement pattern (two generations of dentition, deciduous and permanent), which is a characteristic feature of mammals, in contrast to the polyphyodont reptiles. The evolution of dental exchange went towards the decreasing number of teeth being replaced. This paper aims at providing readers with information on main stages of the process initiated over 200 million years ago, which resulted in a notable diversification of both the dentition patterns and dental replacement types, observed in living mammals.

Key words: dental replacement, diphyodonty, mammalian evolution, polyphyodonty 